\title{
THE INTERNAL RELATIONS OF GOVERNMENT: CAUTIONARY TALES FROM INSIDE THE BLACK BOX
}

\author{
Peter L. StRa uss* \\ I \\ INTRODUCTION
}

B oth the structure of the Constitution and elementary civics texts imagine an Executive B ranch under the close, unitary control of an elected chief executive, the President. D oubtless from the start, and unmistakably in the administrative state, the reality has been quite different. Those to whom Congress has delegated authority to act, particularly in that domain that we have in mind when invoking a "government of laws,"1 conduct their business within a web more aptly described as coordination than control. ${ }^{2}$ In regulatory matters, the coordinating impulses run through the D epartment of J ustice ("D O J ") and, increasingly, the O ffice of Information and R egulatory A ffairs ("OIRA") of the presidential O ffice of $M$ anagement and Budget ("OM B"). Perhaps as strongly, coordination may result from the regulators and their lawyers understanding themselves to be part of a single government. $Y$ et, both within the DOJ and within any given agency, distortions of perspective that are the product of an actor's task, or perhaps even personal ambition, can complicate its achievement. A nd institutions for forcing consideration of broader, more inclusive visions are few.

What follows is an effort to explore some of these problems, drawing on personal experience as a government attorney often faced by what seemed failures or distortions in attempted coordination. From 1975 to 1977, I was privileged to serve as $\mathrm{G}$ eneral Counsel to the spanking new U nited States N uclear R egulatory Commission ("NRC"). The NRC was an independent regulatory

\footnotetext{
Copyright $\odot 1998$ by Law \& Contemporary Problems

This essay is also available at http://www.law.duke.edu/journals/61L CPPStrauss.

* Betts Professor of $L$ aw, Columbia U niversity.

With thanks to J ohn M anning, who read and commented thoughtfully on an earlier draft.

1. M arbury v. M adison, 5 U.S. (1 Cranch) 137, 163 (1803). Excluded from this account are functions like foreign relations and national security, where, in Chief J ustice M arshall's words, "the heads of departments are the political or confidential agents of the executive, merely to execute [his] will ... [so that] nothing can be more perfectly clear than that their acts are only politically examinable." Id. at 166.

2. See generally Peter L. Strauss, The Place of A gencies in G overnment: Separation of Powers and the Fourth Branch, 84 Co LU M. L. REV . 573, 660-67 (1984).
} 
commission created out of one rib of the A tomic E nergy Commission. ${ }^{3}$ I ts very newness and the special character of its responsibilities created opportunities to consider the legal relations within executive ${ }^{4}$ government that remain timely sources of concern two decades later. Three vignettes, all involving relations with government attorneys in other offices, will suggest some dimensions of the problem.

\section{A. What D oes It M ean to B e a Client?}

B rookhaven $\mathrm{N}$ ational Laboratory has a nuclear reactor that generates radioactive waste fuel. A s B rookhaven is located on L ong I sland, in N ew Y ork state, virtually all routes for moving that waste, whether by land or water, lead naturally through $\mathrm{New}$ Y ork City, and for years it had shipped its waste out through the city. Through a newly adopted ordinance pursuant to its $\mathrm{H}$ ealth Code, New Y ork City sought to bar any transshipment of radioactive waste through the city as a health hazard to its citizens. That prohibition raised preemption questions in a rather complex legal framework.

A t about the same time as the NR C was created, enactment of the $\mathrm{H}$ azardous $M$ aterials Transportation $A c^{5}$ made the $D$ epartment of Transportation the national regulator of hazardous materials transportation. The A ct authorized the D epartment to adopt rules governing transportation of this material, rules that would ordinarily preempt conflicting rules of states and localities. ${ }^{6}$ Where conflicts occurred, the A ct gave states and localities an opportunity, through an administrative proceeding, to persuade the Secretary that their adoption of more stringent regulations imposed no excessive burden on interstate commerce. ${ }^{7}$ The Department had not yet adopted any rules, and perforce $\mathrm{New}$ Y ork City had not invoked these new and unexplored administrative procedures. In the meantime, the City's rules not only blocked interstate commerce but also threatened a national laboratory; thus, conventional constitutional analysis suggested the possibility of direct judicial relief. A the same time, one can imagine the general political concerns this new measure fueled, generating public and political support for the city's objections to the passage of radioac-

3. The A tomic E nergy Commission was another "independent" body, but one whose responsibility for developing nuclear weaponry as well as the peaceful uses of atomic energy produced strong ties to the Executive Branch, ties acknowledged in transferring those aspects of its responsibilities to a cabinet department, the D epartment of E nergy.

4. A s the following pages will make clear, whether the NRC was "in" the Executive B ranch was, itself, an open question. The concept of the "independent regulatory commissions" is sometimes presented as if the answer to that question could be negative. No one could doubt, however, that what it did was no more or less than what undoubtedly executive branch agencies do on a daily basis. My own judgment, see Strauss, supra note 2, is that the independent regulatory commissions must be regarded as being in the Executive Branch for constitutional purposes, al beit under a more restricted set of relationships with the President than cabinet agencies enjoy. B e that as it may, wherever they "are," their function is best described as "executive."

5. Pub. L. N o. 93-633, Title I, § 102, 88 Stat. 2156, supplanted in 1994 by Pub. L. N o. 103-272, 108 Stat. 1379, (codified at 49 U .S.C. §§ 1501-1527 (1994)).

6. See 49 U.S.C. § 5103 (1994).

7. See 49 U .S.C. § 5125 (1994). 
tivity-laden trucks through its streets. A nd, in the world of federal regulation, the D epartment had some interest in effecting its new authority.

Whether at B rookhaven's instigation or in some other way memory does not recall, the possibility of initiating litigation to declare N ew Y ork City's new ordinance unconstitutional wound up in the hands of a young attorney in the office of the U.S. A ttorney for the Southern District of New Y ork. It quickly became apparent that he would decide whether we would go immediately to court or wait for the Department of Transportation first to adopt a rule (which might or might not permit continued road carriage of spent nuclear fuel through a large metropolis) and then to assess the city's special circumstances. The Nuclear R egulatory Commission, the Department of Energy, even the D epartment of Transportation and the D epartment of J ustice, would certainly be consulted; but the decision would be taken in the young attorney's office. That is, national transportation policy was being made, not by the agencies concerned, but by an assistant U.S. A ttorney. Perhaps unsurprisingly for a young attorney with a reputation to make, the decision was to sue at once, and, not much more surprisingly, the government lost. ${ }^{8}$

\section{B. W hat K ind of R elationship Do W e Have with the President?}

The NRC's Commissioners were perhaps understandably ambivalent about the meaning of their "independent" status. In contexts with foreign relations sensitivity-notably, licensing nuclear fuel for export-they did not think they could simply accept at face value the diplomatic and security assessments of the State D epartment and the CIA . R ather, they thought, their "independence" required of them some form of independent review. On the other hand, they welcomed presidential interest in their actions and had no doubt that they should deal with him as "team players;" they volunteered participation in O M B consultative activities and generally waited for a response from OMB before acting on any matter on which it might have a view. In one such case, OMB routinely forwarded to the NR C for comment proposed legislation for regulating the use of executive privilege. The bill provided standards for its exercise and required that it be exercised personally by the President; it also limited the reach of executive privilege to the Executive Branch, narrowly construed. If enacted, the bill would foreclose a Commission claim of executive privilege in relation to either confidential State Department documents in its files or, for that matter, security plans for nuclear power plants or materials describing nuclear weapons technology the files might contain. The Commission sent back comments, pointing out that if the bill were to be enacted, it would be imperative to amend it to include the NRC in its scope. That issue was put before the Department of J ustice's Office of Legal Counsel, which responded that the NRC was simply wrong. As an independent regulatory commission, the NRC

8. The litigation continued well into the 1980s; the final chapter appears to have been written in City of N ew Y ork v. U nited States D ep't of Transp., 700 F. Supp. 1294 (S.D.N.Y. 1988), which well describes the earlier stages. 
could not expect to have the protection of executive privilege even with regard to informational demands that demonstrably threatened national security. The position the NRC urged would not be taken.

\section{The Litigation Tail and the Policy Dog}

The litigation that would become Vermont Y ankee Nuclear Power Corp. v. Natural Resources D efense Council, Inc., ${ }^{9}$ had been briefed by lawyers for the A tomic E nergy Commission in the months before the NR C's founding, and argued in the D.C. Circuit in the spring of 1975. The litigation grabbed the Commission's attention on J uly 21,1976 , fourteen months later, when the D.C. Circuit announced an opinion that threatened to suspend all licensing of nuclear power plants pending the Commission's reconsideration of an important, complex, and highly contentious rulemaking. ${ }^{10}$ Responding to that opinion posed a number of interesting challenges, from whether to call the court's attention to striking errors in reading the record whose correction might weaken the case for Supreme Court review, to how it might be possible for the Commission to continue to license nuclear power plants in the interim before Supreme Court action or the generation of a new rule.

Prominent among these challenges were the Commission's discussions with the Solicitor $G$ eneral's office about the filing of a petition for the writ of certiorari. The D.C. Circuit's opinion was perhaps intentionally murky, but the Commission understood its general drift to require extensive use of oral procedures in any renewed rulemaking on remand. The appropriateness of this interpretation was reinforced by the opinion's authorship: Chief J udge D avid L. Bazelon's general preference for procedural elaboration in scientifically contentious rulemakings was well-established and recently had been forcefully voiced. ${ }^{11}$ So, as it prepared for a proceeding that would deploy the expensive procedures it understood the D.C. Circuit to have required, the Commission sought the Solicitor General's support for the position-ultimately vindicated beyond fondest hope- that that court had no business doing so. The process began with the inevitable memoranda and eventually led to a lengthy afternoon meeting at the Justice D epartment. The Solicitor General agreed that courtimposed procedural requirements for informal rulemaking would have been both unlawful and sufficiently important to support a government petition for certiorari. In his judgment, however, it was not sufficiently clear that the opinion had imposed procedural requirements. He thus declined to file a petition for certiorari, advising the Commission to conduct the proceedings on remand without using any procedure it did not itself think justified and promising that if the Commission were reversed again, his office might then think the matter

9. 435 U .S. 519 (1978).

10. See Natural R esources Defense Council, Inc. v. U nited States Nuclear Regulatory Comm'n, 547 F.2d 633 (D.C. Cir. 1976).

11. See Ethyl Corp. v. E PA , 541 F.2d 1, 66 (D.C. Cir. 1976) (en banc) (Bazelon, J., concurring); cf. id. at 68 (L eventhal, J., concurring). 
ripe for the Court. Since the private utilities involved were going to file a petition in any event, however, he agreed that his office's responsive filing, although filed in opposition to the granting of the writ, would both state the Commission's position in a footnote and indicate in the text that if the Court thought his assessment erroneous- that is, if the Court concluded that the matter was ripe for decision-the U nited States supported the Commission's view on the merits.

\section{COORDINATING THE LEGAL WORK OF GOVERNMENT}

In each of the foregoing vignettes, government lawyers spoke to each other across agency lines, seeking essentially collaborative ends. O ther issues are presented by the occasional conflict between opposing agencies, whether in formal litigation or in situations in which one agency falls under the general regulatory jurisdiction of another. In the world of the vignettes, cooperation and service are, or at least one might think ought to be, the order of the day. $Y$ et, as these vignettes perhaps reveal, formidable obstacles may nonetheless arise.

The very size of government is in itself an obstacle, diffusing responsibility and fostering anonymity. A nd, outside the arena of litigation, where the Attorney $\mathrm{G}$ eneral is generally in command, that inevitable effect is compounded by the general absence of mechanisms for cooperation among the government's lawyers on issues of joint concern. ${ }^{12}$ G overnment lawyers function as attorneys for the D epartment of J ustice, the Securities and Exchange Commission, or the D epartment of A griculture-or perhaps for smaller units of any one of those. A ny one of these offices may be of a size that, in the private world, converts the ideal of partnership into a much more impersonal business. In this environment, opportunities for meeting on common ground, identifying and working out shared problems, are scarce.

Thus, the A dministrative Conference of the U nited States, which once constituted a kind of meeting ground for consideration of common issues of administrative law, has disappeared. ${ }^{13}$ The $O$ ffice of I nformation and R egulatory A ffairs in OMB and the Vice President's Office (notably the National Performance Review) have provided, for some purposes, a common meeting ground and forum for the resolution of inter-agency disputes. The $O$ ffice of Legal Counsel in the D epartment of J ustice provides formal advice in a relative

12. See 28 U .S.C. §§ 516-519 (1994). The A ttorney G eneral's sway, even in the litigation context, is limited by the possibility of statutory exceptions-common in the independent regulatory commission context, and not unknown even outside that setting, compare Federal Election Comm'n v. NRA Political Victory Fund, 513 U .S. 88 (1994) - and by the proposition that it is only litigation, and not associated agency decisionmaking, that she is entitled to control, see, for example, Hughes A ircraft v. U nited States, 534 F.2d 889, 901 (Cl. Ct. 1976).

13. See Symposium, The A dministrative Conference of the U nited States, 30 A R IZ. ST . L J . 1 (1998). 
handful of situations. ${ }^{14}$ The Federal Bar A ssociation offers some possibilities for voluntary association. Y et the very enormity of the government's lawyering establishment works against inter-office communication not driven by a particular, relatively urgent controversy or other need.

Consider in this respect an issue common to all regulators: whether, to what extent, and how information about regulatory requirements should be made available on the Internet. This represents a matter of some interest to government attorneys (and the public that deals with them). R ecent years have witnessed the exponential growth of the "information superhighway," warmly embraced by the Clinton A dministration. The Paperwork R eduction A ct of $1995^{15}$ imposed on both OIRA (as coordinator) and on individual agencies responsibilities, inter alia, for "enhancing public access to and dissemination of information, using electronic and other formats." ${ }^{16}$ Doing so would bring a welcome improvement in the transparency of government, enhancing the accessibility of information about regulatory requirements and interpretations. In an era of near universal generation of government documents by word-processing, it is trivial to give electronic access to regulations, proposals for action, interpretations, and any other matter required by law to be available to the public. Y et it remains the case, almost three years later, that "the federal government's web sites are many, yet many seem constructed largely as tourist attractions, rather than serious centers for information dispersal; few if any agencies yet make rulemaking or its documents electronically accessible." ${ }^{17}$ A visitor to those sites, even for agencies located within the same department, often finds no evidence that people have worked with one another to establish what material should be available, much less a predictable format for discovering it. ${ }^{18}$ For example, although all agency regulations published in the Code of Federal R egulations and all Federal R egister notices are in fact on line and fully searchable through a Government Printing O ffice website, among other means, ${ }^{19}$ agency

14. See 28 CFR $\S 0.25$ (1997). "Executive departments" - meaning the very top of the agencymay request an opinion of the A ttorney G eneral, 28 U .S.C. $\S 512$ (1994), but they are under no obligation to do so and, short of litigation, it appears that her view would not control. 1996)).

15. Pub. L. No. 104-13, § 2, 109 Stat. 163 (1995) (codified at 44 U.S.C. §§ 3501-3520 (Supp. II

16. Id. at $\S 3505(a)(3)(B)$ (ii).

17. Teachers Manual for StRA U SSET AL., GELLHORN'S\& BYSE'S A DMINISTRATIVE LA W: CASES AND COMMENTS (9th ed. 1995).

18. In the Department of A griculture's web site, for example, see U nited States Department of A griculture, H ome Page (visited O ct. 12, 1998) <http://www.usda.gov>, the A gricultural M arketing Service, Farm Service A gency, and Forest Service permit searching agency documents (using different search engines), but give no direct access to agency regulations; the Food Safety and Inspection Service, G rain Inspection, Packers and Stockyards A dministration, and rural development agencies provide their regulations but no search capacities; only the Forest Service appears to give access to matters currently open for public comment; only the Office of Departmental A dministration appears to give access to interpretive advisories; and so forth. See U nited States A griculture Department, A gencies and Staff O ffices (visited O ct. 12, 1998) <http://www.usda.gov/agencies/agencies.htm>.

19. See National A rchives and Records A dministration, Code of Federal Regulations, (last modified A ug. 4, 1998) <http://www.access.gpo.gov/nara/cfr/index.html>. The G overnment Printing Office search page, see Government Printing O ffice, Connect to D atabases O nline Via GPO A ccess (last 
web pages do not point in that direction. This failure strikingly reflects this absence of coordinative imagination and effort.

Consider also the developments in administrative law, relevant to all regulators and the subject of important legislative initiatives for the past several years. Each agency encounters its issues- how to conduct rulemakings, adjudications, and other elements of its affairs - in the context of its own responsibilities. The government lawyer does not spontaneously learn what is going on in other agencies or the outcome of judicial review of the proceedings that might affect the affairs of her own agency. When important issues arise in a litigation context, even in the Supreme Court, it is possible, but in my experience rare, that the Department of J ustice will consult broadly on their possible implications. If legislation is proposed, the O M B will seek her agency's view, but that is a rather hierarchical process, with no assurance of participation in discussions or influence on the final shape of testimony. ${ }^{20}$ In either event, her agency's limited resources will often constrain the effectiveness of its participation. Of course, the government lawyer reads- within the time constraints of her formal responsibilities and the scope of her agency's library budget. Perhaps she will be sent, as I was, to conferences run by the Brookings Institution or similar service providers who staff a variety of government "continuing education" programs. On her own time, she may participate in bar association consideration of general legal issues, albeit without government subvention and under conflict of interest rules that limit the bar's capacity to relieve her of expenses private law firms generally subsidize. U ntil two years ago, her agency's general counsel would have been a member of the A dministrative Conference of the U nited States, whose small permanent staff, slender research budget, and biennial meetings identified common problems and provided occasional fora for their discussion. The Conference's $\$ 1.5$ million annual budget was sacrificed to deficit reduction by a Congress perhaps happy enough to diminish the opportunities bureaucrats had to learn from one another. W hite H ouse substitutes, bruited about from time to time, have not securely emerged. A s my experience was then, I suspect it is still: I solation is a predominant experience of the government attorney, perhaps especially within the independent regulatory commissions.

A dramatic, if poignant, example of this isolation appears in the literature, in relation to the National L abor R elations Board ("NLRB"). That agency notoriously made no significant use of rulemaking for policy development through the 1980s. While occasionally using rulemaking to develop procedural

modified A ug. 7, 1998) <http://www.access.gpo.gov/su_docs/aces/aaces002.html>, also permits one to specify searches of the annual U nified A genda of federă regulatory activity.

20. For example, in recent congressional testimony about general regulatory reform proposals I have had the opportunity to attend, the EPA has consistently been present, but not representatives of old-line regulatory departments (Interior, A griculture, Labor, HHS) or independent agencies (SEC, NRC, FTC). Of course, the E PA had very high stakes in the issues being discussed, and the absence of others from the witness table did not prove their absence from the process by which administration testimony was prepared. They, too, however, had high stakes in these matters, and the EPA 's interests may have been quite different from their own in important respects. 
rules, it developed its substantive labor policy almost exclusively through caseby-case administration. Unsurprisingly, as rulemaking came to be the preferred means for general policy development, the NLRB became embroiled in litigation over its reticence to use it. ${ }^{21}$ Professor $M$ ark Grunewald has chronicled the NLRB's subsequent, hesitant exploration of the rulemaking procedure. $^{22}$ The Government in the Sunshine $\mathrm{A} \mathrm{ct}^{23}$ enabled him to give us transcripts of relevant Board discussions; those discussions suggest not only a considerable level of naivete about the rulemaking procedures the Board was exploring but-as striking for these purposes- no evidence of consultation outside the agency for "expert help" in establishing a procedure whose dimensions, by this time, were well-known. ${ }^{24}$ The NLR B's N otice of Proposed R ulemaking ${ }^{25}$ reflects awareness of the controversy over its own rulemaking much more than awareness of the general literature on the subject or general agency experience in implementing it. W ithout evident discussion, ${ }^{26}$ the B oard chose a hybrid form of procedure whose tendencies to produce complexity had been noted in other settings. ${ }^{27}$ The Board's encounter with rulemaking in this manner appears to have been definitive; it seems hardly to have tried it again. ${ }^{28}$

It is unlikely that we will see the size of either government or its legal establishment shrink significantly. That ought to underscore the need for centripetal institutions, as the A dministrative Conference formerly was, through which problems can be shared across agency lines. $Y$ et, in the tensions produced by efforts to balance the budget while still achieving government's ends, resources for coordination and interchange may easily seem the most expendable. The Vice President's office and OIR A, steadily emerging in the last several administrations as the political and technocratic managers, respectively, of

21. See N LR B v. Bell A erospace Co., 416 U .S. 267 (1974); NLR B v. Wyman-G ordon Co., 394 U .S. 759 (1969); cf. A merican Hosp. A ss'n v. NLRB, 499 U.S. 606 (1991) (denying a challenge to the NLR B's decision to use its broad rulemaking powers).

22. See Mark H. Grunewald, The NLRB's First Rulemaking: An Exercise in Pragmatism, 1991 DUKE L.J . 274. To date, the rule involved in Grunewald's article, 29 C.F.R. § 103.30 (1998), also appears to have been the NLR B's last rulemaking.

23. 5 U .S.C. § 552b (1994).

24. STRA USSET AL., supra note 17 , at $432-34$.

25. Collective Bargaining U nits in the H ealth Care Industry, 52 F ed. R eg. 25,142 (1987).

26. Seeid. at 25,148 .

27. See generally Barry B. Boyer, Trade Regulation Rulemaking Procedures of the Federal Trade Commission, in A DM INISTRA TIVE LA W CONFERENCE OF THE U.S.: RECOMMENDATIONS \& REPORTS 41 (1979); B arry B. B oyer, Trade R egulation Rulemaking P rocedures of the Federal Trade Commission (Phase II), in ADMINISTRATIVE LAW CONFERENCE OF THE U.S.: RECOMMENDATIONS \& REPORTS 33 (1980).

28. No other similar rule appears in Title 29 of the Code of Federal R egulations. The two most recent $U$ nified A gendas of Federal R egulatory and Deregulatory A ctions, see 62 Fed. Reg. 22,716 (1997); id. at 58,468 (1997), reveal that in 1994 the Board began consideration of a rule that might have limited litigation over the appropriateness of petitioned-for single-unit bargaining units, see A ppropriateness of R equested Single L ocation Bargaining U nits in R epresentation Cases, 59 Fed. R eg. 28,501 (1994); 60 Fed. Reg. 50,146 (1995), but that further action on that proposal has been blocked by appropriation riders forbidding the expenditure of funds on the proceeding. A II other items listed-four in A pril, two in $\mathrm{O}$ ctober-were procedural in character. The FTC, by way of contrast, listed more than 20 rulemakings pending in each of those agendas, the great proportion of them substantive in character. 
day-to-day domestic government, perhaps could serve to build government's cohesion-to serve, as it were, as hubs of the wheels of regulation. Y et, their very authority can also work against their success. The exercise of their political or legal authority to issue commands to the agencies that work with them can convert general concerns for governmental operation into struggles over particular outcomes-the more immediate, the more easily identified, apparently the more worthy of effort and expenditure in the short run-and that in itself can undercut the coordinative impulse. Building institutions that are genuinely consultative, and that merit the expenditure of resources on all sides, would prove no small task.

III

\section{The Relation of Independent A genciesand the President}

O ne regular aspect of the General Counsel's work at the Commission was preparing correspondence with the White $\mathrm{H}$ ouse concerning legislative proposals, both the Commission's own and those sought by other agencies on which O M B sought the Commission's views. The O M B's circular on legislative coordination and clearance sets exacting requirements for internal consultations in the $E$ xecutive $B$ ranch before virtually any conversation with Congress, whether it concerns the submission of proposed legislation, reports, or hearing testimony. ${ }^{29}$ The circular gives "agency" a sweeping definition, explicitly embracing the independent regulatory commissions, yet accepting that Congress will sometimes have sought to limit their cooperation with White $\mathrm{H}$ ouse processes. ${ }^{30}$

Internally, it could not have been clearer that the NRC's Commissioners valued these consultations. Whatever might have been their legal right to proceed on their own, both their sense of the "teamwork" appropriate to government and their knowledge of the benefits that O M B goodwill might bring motivated them to cooperate with these processes. They expended efforts on these communications commensurate with what they gave to Congress (and rather more than on communications with the courts, where the G eneral Counsel was generally left to his own devices), and were willing to risk congressional disfavor by delaying response or cooperation pending O M B's advice. Particularly if one felt that this was not a matter of legal obligation, it could be frus-

29. See L egislative Coordination and Clearance, OM B CIR CULAR A -19 (Sept. 29, 1979) <http:// www.whitehouse.gov/W H/E O P/O M B /html/circulars/a019/a019.html>.

30. The Circular provides the following:

4. Coverage. All executive branch agencies (as defined in section $5 b$ ) are subject to the provisions of this Circular, except those agencies that are specifically required by law to transmit their legislative proposals, reports, or testimony to the Congress without prior clearance. OM B will, however, honor requests from such agencies for advice on the relationship of particular legislation, reports, or testimony to the program of the President.

5. DEFINITIONS. For the purpose of this Circular, the following definitions apply: ...

b. A GENCY. A ny executive department or independent commission, board, bureau, office, agency, Government-owned or controlled corporation, or other establishment of the GovId. ernment, including any regulatory commission or board. 
trating to be under instructions to delay putting forward requested advice, whose influence might thereby be diminished. $Y$ et it was easy to grasp the impulses underlying the Commission's preference: Congress was not, after all, entitled to abstract the agency completely from the one elected head of executive government; coordination of agency actions was desirable both to encourage initiatives consistent with the President's program and to identify, if not discourage, those that were not. Congress might structure the Commission's relationship with the President, but it could not deny it one.

More striking were the attitudes suggested by the second opening vignette- encountered as strongly in the office of the President's lawyer as in conversations with lawyers at other independent agencies-that in fact the Commission had no proper relation with the Executive Branch. Perhaps this was largely the product of realpolitik, a White House conclusion that fighting with Congress over legal dominion was not important enough for the political costs of taking that position. In the series of executive orders leading up to the current Executive 0 rder 12,866 (requiring economic impact analyses in connection with important rulemakings), the White House has explicitly declined to involve the independent regulatory commissions, although acknowledging legal opinions that it has the authority to do so. ${ }^{31}$ If so, the politics may be changing. Congress, once reflexively protective of the independents, seems to be acknowledging the utility of central oversight and coordination, at least as to some issues. The Paperwork R eduction A ct reserves a role for OIR A in relation to them, as to executive agencies, albeit under somewhat modified conditions, ${ }^{32}$ the R egulatory Flexibility $\mathrm{A} \mathrm{ct}^{33}$ and more recent drafts of rulemaking reform legislation providing for executive oversight of rulemaking do not differentiate between independent and departmental agencies. No one doubts Congress's authority thus to involve the President; what seemed the President's lawyers' easy acceptance of its authority to exclude him is what prompted my wonder, and a good deal of my subsequent writing. ${ }^{34}$

Two decades later, separation of powers law has evolved in ways that make incredible any contemporary assertion by the O ffice of Legal Counsel that independent agencies cannot find shelter under the President's wing. This must be a primary lesson of Freytag v. Commissioner, ${ }^{35}$ which so sharply delimited the range of persons Congress could empower to make appointments of "Officers of the U nited States," within the meaning of the Constitution's appointments clause. ${ }^{36}$ "A ny appointee exercising significant authority pursuant to the laws of the U nited States," the Freytag Court said, must receive her

31. See Peter L. Strauss $\&$ Cass Sunstein, The Role of the President and OMB in Informal Rulemaking, 38 A DMIN. L. REV. 181, 202 (1986).

32. See 44 U .S.C. § 3503 (Supp. II 1996).

33. 5 U .S.C. §§ 601-612 (1994).

34. See, e.g., Strauss, supra note 2 .

35. 501 U .S. 868 (1991).

36. U .S. CONST. art. II, § 2, cl. 2. 
commission from the President (with or without Senatorial assent), one of the $\mathrm{H}$ eads of D epartments, or the courts. ${ }^{37}$

Where does that leave appointment as G eneral Counsel of the NRC? My commission was signed by the NRC's Commissioners, not the President. The NRC is surely not a "court." I ts general counsel is surely an "Officer of the U nited States," given the Court's capacious description (and Congress's designation of the post as worthy of executive-level compensation). If lawfully appointed, then, it must be because I owed my commission to A rticle II "Heads of Departments." A ctually, the majority opinion in Freytag renders even this conclusion dubious; it goes on at regrettable (and in my judgment unnecessary) length about how a "Department" can only be a part or division of executive government expressly created and given the name Department, citing a century-old case that had no need to decide any so sweeping a proposition. ${ }^{38}$ It would be hard to bring the NRC (or even the undeniably executive branch EPA ) under that umbrella. But even if one took a broader view of who were "H eads of D epartments" (as J ustice Scalia, concurring in Freytag, believed one must ${ }^{39}$ ), that very conclusion puts the NRC in A rticle II, within reach, for example, of the President's authority to demand "the O pinion, in writing, of the principal Officer in each of the Executive Departments, upon any subject relating to the $D$ uties of their respective 0 ffices $^{\prime 40}$ - and hence, under the President's wing, and within the protection (such as it is these days) of executive privilege.

From the general perspective of being a government lawyer, however, perhaps the most striking characteristic is how undeveloped the "law" is on such central organizational issues. For my office, feeling its way through relations with the Department of State (much less the White House) presented challenges of constant improvisation with few guideposts, however high the stakes. $U$ sed to imagining behemoth, anthropomorphized government-certainly, the anthropomorphized agency-one's constant experience from the inside was of barely coordinated chaos. Few lawyers will be surprised, perhaps, how often seat-of-the-pants judgment is one's principal professional tool; or that the internal experience of a seemingly huge and seamless bureaucracy is of diffuse and uncoordinated authority. Nonetheless, the room for difference, for uncertainty about true fundamentals, for petty autocracy-and, yes, also for initiative and responsibility-never ceased to astound.

IV

\section{GOVERNMENT LITIGATION}

The preference for rulemaking over adjudication as an instrument of agency policy formulation carries with it the implication that litigation is not a par-

37. F reytag, 501 U .S. at 881.

38. U nited States v. G ermaine, 99 U .S. 508 (1879).

39. Freytag, 501 U.S. at 918 (Scalia, J ., concurring).

40. U .S. CONST. art. II, § 2, cl. 1. 
ticularly good policymaking tool. While the notion that an agency will be able rationally to choose between them in particular circumstances is a polite fiction, and adjudication may offer more scope for initiative to the particular players who are responsible for initiating and conducting it, ${ }^{41}$ agency litigators are rarely the individuals given principal operating responsibility for agency policy formation and implementation. Nor do they often have a broad and comprehensive view of agency function and needs. Litigation processes produce views of the issues involved that are notoriously dependent on particular (and likely atypical) facts; and they are highly dependent on individual rather than collective effort. A ll of these distortions can be more pronounced when the litigator works outside the responsible agency.

A s an independent regulatory commission, the NR C had more control over its litigation, for better or worse, than would a cabinet department. In general, its own lawyers appeared on its behalf and controlled its filings. The world of litigation was where the lawyers came into their own. No other players within the agency purported "expertise" in this field. The Commissioners themselves, not lawyers save one, depended uniquely upon their lawyers for advice.

In the peculiar structure of the NRC, that left a certain amount of room for competition. Its small General Counsel's Office advised the Commissioners themselves, prepared their opinion, legislative testimony, and correspondence with $O M B$, and represented the Commission in court. The larger office of the Executive Legal Director represented its staff of about 2,000, presented the agency's side at administrative hearings, conducted its rulemakings, and drew up its contracts. The two offices occasionally struggled over what fell in whose camp or whose view of legal consequences was the sounder. Probably these struggles enlarged the Commissioners' operative freedom of action, by making apparent the availability of choices a unified legal office might not have identified.

Y et, the largest risk was the one created both by lawyers' unique domain over and expertise in litigation, and by the arguable distortions that concern over litigation occasioned in their judgment. The risk was that the two offices would make common cause against other offices in the Commission, enlarging lawyers' domains at the expense of others', by flaunting the banner of adverse "litigation consequences" as reasons why their judgment ought to carry special weight. Doing so, after all, was a way to make one's voice distinctively heard. In fact, it was not litigation, but planning and counseling that made life in the General Counsel's office particularly distinctive and rewarding. O ne was shaping the future, charting events whose outlines could be only dimly grasped. In these settings, though, whether preparing for legislative testimony or helping the NRC understand its options in evaluating and pursuing a desired course of action, the work of the office was not unique. Other agency offices, both re-

41. See Peter L. Strauss, Rules, A djudications, and $O$ ther Sources of $L$ aw in an Executive Department: Reflections on the Interior D epartment's A dministration of the M ining L aw, 74 COLUM. L. REV. 1231 (1974). 
sponsible bureaus and competitor staff offices like the Office of Policy Planning, were equally present at the table and attempting to have their say. J ealousies about what was for lawyers, and what for engineers, often surfaced. B ureaucratic politics was frequently the mode of operation. "Litigation consequences" was-and is - a tempting weapon in the lawyer's arsenal.

How "litigation consequences" can drive agency behaviors is a clearly marked hazard of agency life, a hazard that underlies much of the current debate about the ossification of rulemaking. Controlling its use as an argument on policy issues inside the NRC might be thought to be a problem similar to that faced by any private attorney in relationship to her client: A large part of professional responsibility is preserving client autonomy, and in this context that means raising the "litigation consequences" argument only with great caution. Concern to control the argument's use animated much of my office's dealings with the Commissioners and, especially, with the separate O ffice of the Executive L egal D irector.

E ven more striking, however, were the ways in which external litigators and litigation, lacking any obligation or likelihood of loyalty to the Commission's agenda, drove agency business. The efforts of adversaries in this respect warrant no special attention; that litigation is among the tools "public interest" litigators and others use to attempt to control agency priorities is commonplace, and threshold doctrines such as standing and ripeness recognize and seek, to a degree, to control the risk. Here it seems more useful to turn to the complications introduced by having outside counsel for one's own case.

The D epartment of J ustice works much harder to control government appeals from adverse trial judgments than it does the initiation of litigation in the first place. ${ }^{42}$ Perhaps one should understand this choice in terms of the resources that might be required, and of the differing systemic implications for the government as a whole of controlling trial actions rather than simply vetting appeals. The first of the vignettes sketched in the opening pages of this essay, the B rookhaven waste litigation, was nonetheless a sharp lesson in the resulting possibility of governmental chaos. However the impulse to litigation had been created, early discussions among lawyers for the agencies concerned-the NR C and the Departments of Energy and Transportation-quickly developed an understanding that the problem could be dealt with proactively under the new but not yet effective procedures made possible by the $\mathrm{H}$ azardous $\mathrm{M}$ aterials Transportation A ct of $1994 .^{43}$

B ut none of these lawyers was in charge of the litigation. The young A ssistant U S. A ttorney from the Southern D istrict of N ew Y ork had the U nited

42. No appeal from adverse action in the district court or petition for rehearing en banc in the courts of appeal may be filed without the permission of the Solicitor General, a process that can be as extended as securing his approval for the filing of a petition for a writ of certiorari in the Supreme Court, when an agency has lost its case in one of the courts of appeal. No similar coordinating process or constraint governs the initiation of litigation.

43. Pub. L. N o. 103-311, title I, 108 Stat. 1673 (codified as amended at 49 U .S.C. §§ 5101-27 (1994 \& Supp. II 1996)). 
States as his client, the U.S. A ttorney for the Southern D istrict as his senior partner, and the A ttorney $G$ eneral as no more than a remote adviser in distant Washington, D.C. Whatever the formal legal authority of the A ttorney General over a U.S. A ttorney, the political situation is one of limited control. Those officers, too, are presidential nominees, confirmed by the Senate and often important to the Senators of their districts. O ver the years, the office in the Southern District of New $\mathrm{Y}$ ork, in particular, had acquired a practical independence of J ustice Department direction. That independence occasionally raised eyebrows or caused knowing smiles in Washington, but the real gesture was the defeated shrug that accompanied it: What, after all, was it possible to do? The A ttorney General would not, could not, micro-manage work in the offices of U S. A ttorneys. The litigation would and did go forward.

The appellate process was much more tightly controlled. Y et, even here, outside lawyers responsible solely for litigation may have difficulty understanding the consequences of their actions for agency behavior. This difficulty marked the Commission's relationships with the D epartment of J ustice, in particular with the O ffice of the Solicitor General. Serving as an attorney in that office at an earlier point in my career, I had understood the contributions it made to government overall: promoting its interests in the Supreme Court by screening government litigation for importance, maturity, and equitable appeal, and counterbalancing the tunnel-vision of particular agencies with a broader view of the government's litigation exposures and needs. What had not been as evident then was the peculiar tunnel-vision that the habit of dealing al ways with litigation can occasion.

By statute and with the Court's blessing, the Solicitor G eneral controls access to the Court for the independent regulatory commissions as well as cabinet departments. ${ }^{44}$ The Supreme Court is, doubtless, well-served by a single office responsible for screening litigation and for expressing the views of "the $U$ nited States." The independence of an NRC finds expression, perhaps, in a greater willingness to convey the views of the agency as well as those of the office, where they differ. In the end, that willingness served the Commission well. On three occasions during my time as general counsel, the Commission sought the Solicitor General's permission to file a petition for certiorari. On each occasion, we came away without permission to do that, but because the private utility filed a petition, the government was obliged to respond. In that response, the Commission's fears as well as the Solicitor General's views could be and were put before the Court. Each of these cases resulted in Court action in the Commission's favor. Perhaps we were simply failing to be as persuasive as we should have been to that $O$ ffice, in so consistently failing to gain its adherence to views that ultimately prevailed.

44. See Federal Election Comm'n v. NRA Political Victory Fund, 513 U.S. 88, 96-97 (1994), see generally Neal Devins, U nitariness and Independence: Solicitor General Control over Independent A gency L itigation, 82 C A L. L. R E V . 255 (1994). 
$Y$ et the third vignette above, the run-up to Vermont $Y$ ankee, may suggest that at least part of the explanation lies in how the $O$ ffice of the Solicitor $G$ eneral's litigation perspective distorted its view. W hat the Commission sought, after all, was not procedural ease but effective, lawful action. Why should it experiment with a risky procedural course-it had taken four years to get from the initiation of rulemaking to the first D.C. Circuit opinion-when it knew how to achieve a result that would prove procedurally acceptable, albeit more expensive to reach? The idea that it would take the risks involved in securing a procedurally well-framed case, rather than act to get its business securely done, marked a kind of disconnect between litigation and programmatic responsibilities that was eye-opening at the time, and has remained so since. ${ }^{45}$ The Solicitor $\mathrm{G}$ eneral's advice, in effect, provided exactly the litigation-avoidance incentives that drive ostensibly voluntary procedural complexity. From the agency perspective, present efficiency gains are easily overcome by the risk that one might learn, years after the fact, that secondary errors have undercut the validity of primary effort. That is the direction in which "litigation consequences" invariably push.

Was the Solicitor General wrong to worry about the concreteness of the case as presented, the clarity with which the issue the Commission wished to raise was presented on its facts? The relevance of the question is hard to deny, both as a matter of risk to broader government interests should the effort to establish a favorable rule of law backfire and as a prudential matter of preserving his office's reputation as a protector of the Court's gates. A s the government's lawyer in that forum, he will disserve its interests if seen too easily to accede to agency importunings. In a way, the presentation format he chose permitted the government to have its cake and eat it too: The NR C position was fully articulated, and by voicing his own office's concern about ripeness, he demonstrated to the Court in a very practical way that he was aware of and serving a protective function that might protect its interests.

$Y$ et, one is also left with the conviction that the litigation lens was in fact distorting. $\mathrm{H}$ is advice to "try again, to see if you get a clearer statement" would have imposed on the agency the very harm from which it was seeking to be free. A nd it reflects a failure of understanding easily connected with his responsibility only for litigation and not for the success of an agency's substantive program. From that perspective, one can understand the wish for a sharper, cleaner case, but the idea that that would be the agency's interest, rather than a successful promulgation of its rule, is surely naive. The litigation tail, once again, is wagging too vigorously, at significant risk to the policy dog.

\footnotetext{
45. Compare United States v. Florida E. Coast Ry., 410 U .S. 224, 230-34 (1973), where the recitation of facts makes plain what extraordinary political pressure was required to make the Interstate Commerce Commission choose the risks and speed of procedural efficiency over the costs and delays of procedural certainty.
} 
V

\section{CONCLUSION}

Who is the government lawyer's client is, indeed, a complex question. The adage inscribed on the J ustice D epartment, that the government wins its case in court whenever justice is done, reflects an ambiguity about client loyalty that infects even the most direct of representations. It is, at the same time, a check on public power-no "good soldier" defense will be recognized here-and an invitation to the exercise of personal will. It can be very hard to tell the difference, particularly where the nature of the client is also diffuse. Thus, the difficulties are enlarged by the unsettled character of structural issues within the Executive Branch. Limited domains of hierarchy, limited capacities to secure uniformity, limited settings in which it is even sought-all these conjoin, also, to produce an ambiguity about obligation, within which the individual government lawyer may find considerable room for maneuver. A nd finally, as perhaps in any very large organization, specialization of lawyerly function can produce its own distortions. The litigator's imagined client may be quite other than the planner/counselor's. The two cannot be brought together; it will be rare that a single voice will be heard. In the end, as Francis L ieber remarked in a quite different context, "somewhere we needs must trust at last to common sense and good faith." 46 J acobstein eds., 1970) (1839). 